\title{
The Report of the International Financial Institution Advisory Commission: Comments on the Critics
}

\section{By Allan H. Meltzer*}

When the U.S. Congress approved $\$ 18$ billion of additional funding for the International Monetary Fund (IMF) in November 1998, it authorized a study of international financial institutions. Congressional concerns included the growing frequency, severity and cost of financial disturbances, the fragility of the international monetary system, the ineffectiveness of development banks, and corruption in Russia, Indonesia, Africa and elsewhere. But Congress also expressed concern about whether international financial institutions had adapted appropriately to the many changes since the Bretton Woods Agreement in 1944.

In July 1999, Congress completed appointment of the members of the International Financial Institution Advisory Commission (IFIAC). Between September 9, 1999 and March 8, 2000, the Commission met twelve times and, in addition, held three days of public hearings. On March 8, 2000, it presented its Report to the Speaker and the Majority Leader of the House of Representatives. The Report stimulated active discussion of issues that might have been addressed at the fiftieth anniversary of the Bretton Woods Conference, in 1994, but were not.

Discussion was overdue. As Congress recognized, the world economy and the international financial system are now very different from the world envisioned at Bretton Woods in 1944. The principal international financial institutions responded to many past changes and crises by expanding their mandate and adding new facilities and programs. New regional institutions opened to better serve the needs of regional populations. Many of the activities of these agencies overlap with those of the World Bank.

The Commission had a very broad mandate and a very short life. The U.S. Congress asked IFIAC to evaluate seven major institutions and recommend changes in only six months. The Commission chose to concentrate on the International Monetary Fund (IMF), the World Bank, and the three regional development banks. It gave less attention to the Bank for International Settlements and the World Trade Organization.

There were two broad sets of issues, organizational and functional. The former includes the structure of the institutions and the incentives that motivate individuals. Performance can be improved

\footnotetext{
* I am grateful to Adam Lerrick for many helpful suggestions. An earlier version was prepared for Reforming the Architecture of Global Financial Institutions, C. Gilbert, J. Rollo, and D. Vines, (eds.). Cambridge: Cambridge University Press, 2001. A version of this paper is included also as the introduction to the Spanish edition of the Report of the International Financial Institution Advisory Commission. The author served as Chairman of the IFIAC.
} 
only by changing the incentives under which the staff works and member countries operate. A frequent criticism, discussed almost a decade ago in the Wapenhans report but still not fully addressed, is that the World Bank rewards lending, not poverty alleviation or successful economic and social development. World Bank (1992). A different set of incentives in a restructured organization would focus more attention on benefits to the citizens of client states.

IFIAC started work with ten members, including six economists, so it seemed appropriate to focus attention on economic themes. ${ }^{1}$ There was not enough time to treat all issues adequately. As Chairman, I chose to emphasize the role of the multilateral institutions in supplying services that the private market would not provide and developing infrastructure that would permit market solutions where feasible and non-market solutions elsewhere. An economist's reflex response is to ask: What are the public goods that these institutions can supply effectively? What is their comparative advantage? Where do markets fail? Can an international financial institution effectively and efficiently supply the missing services?

A second set of issues soon became apparent. There is considerable overlap between the Bank and the IMF and between the Bank and the regional banks. The overlap might be justified as a type of competition to provide services to client states at lowest cost. Unfortunately, the overlap and duplication arise for reasons that have little to do with competition or efficiency.

\section{The Framework}

In setting IFIAC's charge, the U.S. Congress recognized that two major changes in international financial arrangements required changes in the responsibilities of the international financial institutions (IFI's). First, the fixed but adjustable exchange rate system, agreed to at the Bretton Woods Conference, ended more than twenty-five years ago. Second, private financial institutions, corporations, and individuals in the developed countries now supply the largest part of the capital flow. The IFI's share is now less than $5 \%$ of the total. The percentage varies across countries, however. Many of the poorest countries remain dependent on the IFI's.

Major problems of the system follow from these changes. Countries rely excessively on shortterm capital inflows to finance long-term development, a very risky approach that has caused crises throughout history. Financial systems in developing countries are, too often, used to subsidize favored industries or individuals, weakening the financial institutions and eroding their capital. This, too, increases the risk of crises and failures. Pegged exchange rates replaced the fixed exchange rate system in

\footnotetext{
${ }^{1}$ The members were: Professor Charles Calomiris, Congressman Tom Campbell, Dr. Edwin Feulner, Jr., Dr. Lee Hoskins, Mr. Richard Huber, Dr. Manuel Johnson, Professor Jerry Levinson, Professor Allan Meltzer, Professor Jeffrey Sachs, and Congressman Esteban Torres. The eleventh member, Dr. C. Fred Bergsten, also an economist, joined in January 2000, after most of the Commission's hearings had ended.
} 
many developing countries, opening the countries to speculative attacks. With weak financial systems dependent on short-term capital, the system became subject to frequent, severe crises.

Further, the IFI's lend to governments and have very little influence over the use of funds. Often projects are not completed; funds are misappropriated, and promised reforms are not implemented. Instead of improving their performance as development agencies, the development banks have expanded their programs to overlap with the IMF. The reverse is also true. The IMF makes long-term loans for structural reform and poverty alleviation. Some countries remain permanently in debt to the IMF.

The majority report responds to these fundamental problems by proposing structural changes in the institutions. The Report gives the IMF and the development banks separate roles. It sees the proper role of the IMF as preventing financial crises and preventing the spread of crises that occur. This is a classic public responsibility--to reduce risk to the minimum inherent in nature and trading practices. It is very different from the role that the IMF has assumed. Crisis prevention does not mean, and in the Commission's majority view should not mean, that the IMF continues to "bail out" all lenders, or lend large amounts to maintain pegged exchange rates, or dictate the policies followed in client countries. Financial stability does not require that all countries follow a "Washington consensus" or that the IMF lend for institutional reform. The IMF should give advice, but it should not tie the advice to assistance. ${ }^{2}$

Lending for institutional reform is one of the tasks of the development banks. The majority believes that their mission should have four parts: promoting economic and social development, improving the quality of life, reducing poverty, and providing global and regional public goods. These institutions should not be banks. Their job should not be to increase the number and size of loans or to lend to creditworthy countries. To recognize that their mission is development, not lending, the Commission's majority recommended that the names of these institutions should be changed to development agencies from development banks.

The World Bank has started to create field offices in recipient countries. The majority believes that this is another waste of resources by an overly large and ineffective bureaucracy. The InterAmerican, Asian, and African Development Banks have offices in all of the relevant countries. Many governments, and their constituents, have closer ties of language, culture, and understanding to the regional agencies. The majority believes that effectiveness would be improved, and costly overlap reduced, if the regional banks assumed sole responsibility for many of the programs in their regions. The World Bank's direct role in transferring resources would be limited to regions without a development

\footnotetext{
${ }^{2}$ Private consultants charge for advice. The IFI's pay or subsidize countries. Many critics of the Commission report argue that countries would not accept advice if it were given without subsidized lending. See U.S. Treasury (2000). This is a peculiar argument. Must countries be bribed to take the advice? Or, do they take the subsidized loan, ignore the advice, or give it lip service only? Russia is an extraordinarily bad example of a country that took the money but not the advice. There are many others.
} 
bank and to Africa, where poverty problems are most severe and difficult to solve, and where the regional bank has less experience. The World Bank would continue to supply technical assistance and promote knowledge transfer in all regions.

Critics contend that this proposal would "undermine the effectiveness of the overall development effort." U.S. Treasury (2000, p. 8), although they have not elaborated this argument. ${ }^{3}$ This criticism avoids discussing the waste from duplication between the World Bank and the regional development banks, but this is not its main omission. The aim of the recommendation is to force the World Bank to concentrate its financial resources on the region with the largest number of very poor countries. The Bank lends mostly to middle-income countries that have investment grade ratings and can, therefore, finance development in the market place.

World Bank management argues that the proposed change would reduce its ability to learn from diverse experience in many parts of the world. This argument is puzzling. Often the most objective and useful examinations are made by those who are not directly involved in a project. They have less incentive to cover over failures and mistakes.

The more important reason, I believe, for opposing the transfer of program responsibilities from the World Bank to the Asian (ADB) and Inter-American Banks (IDB) is very different. The United States has more direct influence over the World Bank. The U.S. Treasury does not wish to see power and responsibility shift to the countries in the region. I believe a shift of this kind is likely in coming years, and it is best to make the transfer in an orderly way. Indeed, in Europe and Asia the movement toward greater regional control is well underway. South America seems likely to follow.

Organizational and structural changes are important, but they are not sufficient to increase operational or program effectiveness. Incentives to make programs work and to reduce waste and corruption must increase. The majority report gives considerable attention to these issues. The World Bank's current administration deserves credit for commenting publicly on corruption. Public comment and exhortation are not enough to create lasting change. Incentives give people reasons to change their behavior. The majority report replaces exhortation and subsidies with strong incentives to improve performance and reform institutions.

The specific proposals in the majority report implement this framework. Our goal was to provide public goods efficiently, effectively, and in ways that give countries and the IFI's incentives to increase economic stability, raise living standards, improve the quality of life for their citizens, and cooperate in providing regional and global public goods

\footnotetext{
${ }^{3}$ There have been many criticisms and comments. Most of the principal criticisms are in the Treasury's mandated response. We refer to it wherever applicable.
} 


\section{The IMF}

The majority proposed that the IMF focus its efforts on four main tasks; crisis prevention, crisis management, improved quality and increased quantity of public information, and macroeconomic advice to developing countries. The Treasury's response endorsed these objectives. Our differences are limited to means, not ends.

Each of the serious crises since 1982 has its own special features and some common features. Before the crisis breaks out, investors begin to withdraw funds. The country often guarantees the foreign exchange value of the funds in an attempt to forestall the emergency. This postpones the crisis but does not prevent it. The IMF tries to help the country maintain its exchange rate by lending foreign currency to defend the exchange rate. The country may increase interest rates and promise reforms, but investors see increased risk. If the financial system depends on short-term capital inflow, it may collapse with the exchange rate. The most damaging crises are of this kind.

The majority does not believe that all crises can be prevented. It does believe that the frequency and severity of crises can be reduced by reforming country and IMF practices to increase incentives for policies and behavior that enhance stability. The IMF should be a quasi lender of last resort, not first resort, providing liquidity when markets close. It should work to prevent crises, act to mitigate them, and leave structural reform and development to the capital markets and the development banks.

The majority proposed to establish pre-conditions for IMF assistance. Countries that met the conditions would not have to wait, as they presently do, while negotiators agree on a long list of structural, institutional, and financial changes. Crises worsen during these delays, so we propose immediate assistance to qualifying countries.

The conditions must be straightforward, clear, easily monitored, and enforced. The majority proposed four conditions, but the list could be altered or expanded slightly. Most important, I believe, are that the financial system is adequately capitalized, government financial policies are prudent, information on the maturity structure of foreign debt becomes available promptly, and foreign banks are allowed to compete in local financial markets. Members of the World Trade Organization have agreed to phase-in this last condition, and several have done so. The majority would speed up implementation as Mexico, Brazil, Argentina, Hungary, Chile, Poland, Czech Republic, Venezuela, Peru, and others have done. See The Economist, (2000, p. 118). The majority recommended that the exchange rate system be either firmly fixed or floating, but it did not include that recommendation as a pre-condition. After further reflection, I would include that condition.

Countries would have strong incentives to meet and maintain the pre-conditions. Once a country qualifies, it would obtain more foreign capital on more favorable terms. IMF acceptance of the country as qualified for automatic assistance would serve as a seal of approval and reduce expected losses. The 
market would have a list of countries that qualified, and a list of those that did not. The latter would get fewer loans and would pay higher interest rates to compensate for the additional risk. Thus, preconditions redirect private sector flows away from high-risk borrowers toward those that pursue stabilizing policies. This reduces the risk in the entire system.

Pre-conditions are not a panacea. They will not increase incentives for stability or induce countries to reform, if the IMF continues to bailout all countries. ${ }^{4}$ Countries that are crisis-prone because they follow profligate policies or use their financial system to finance politically favored projects must have an incentive to change their ways. If the IMF does not allow countries to fail, markets will not distinguish sufficiently between countries with proper and improper policies and standards. Lenders will not have to bear the full risk of their decisions, so they will not charge enough to encourage governments to reform.

What about third countries, countries that are harmed by the collapse of a trading partner? The majority would assist such countries automatically, if they met the pre-conditions. In all other cases, it would help them only if there is a systemic crisis. We recognize that the IMF would have discretionary power. They could, and likely would, stretch the meaning of "systemic." The main risk is not, as several critics suggest, that the IMF would do too little. The more serious risk is they will continue to bail out most countries, thereby reducing the incentive to reform.

Some of the Report's critics claimed that the majority proposal was an effort to curtail the IMF's activities. Much too often, this claim attacks the members' motives and misrepresents the report. The IMF's activities would decline if crises declined, as the majority believes they would. The main reasons for reduced lending would be that there would be less need for lending, if there were fewer crises. And there would be fewer crises if pre-conditions were met. ${ }^{5}$ Financial sectors would be solvent and open to competition from foreign banks, governments would be prudent, and exchange rates would either float, even if not freely, or be firmly fixed and supported by adequate reserves and appropriate policies.

Critics argue correctly that all crises are not liquidity or financial crises. They then claim that the majority report does nothing about other, non-liquidity crises. U.S. Treasury (2000, p. 7). This is a misunderstanding. First, the majority required prudent fiscal policies to remove this source of

\footnotetext{
${ }^{4}$ Several critics, including Treasury (2000) either ignore or miss the role of incentives. The underlying theme of the majority report is that proper incentives are both more powerful than exhortation and, because they are adopted by the country through its own processes, more likely to be accepted. It is not the same to say, "we did this so we could get more investment on better terms" instead of "the IMF insisted that we do this."

${ }^{5} \mathrm{~A}$ frequent criticism is that, if the majority report had been adopted, the IMF would not have been able to assist countries in the Asian crisis. U.S. Treasury (2000, p. 6). This criticism is not correct. The majority endorsed discretionary authority to act in a systemic crisis. Also, the critics do not say whether the reforms had been in place for the five-year phase-in that the majority report proposed. If the Asian countries met the pre-conditions for five years, they would have been much less vulnerable. The problem would have been smaller because countries would have had safer financial institutions and floating exchange rates.
} 
disturbance. ${ }^{6}$ Second, the majority did not neglect structural problems. It assigned these problems to the development banks and, as noted below, proposed to increase incentives for introducing and continuing structural reforms for ten or more years so that the reforms become institutionalized. Removing structural problems from the IMF's mandate is based on a well-known proposition: money can solve liquidity problems, not real structural problems. In developing countries, structural problems arise because of regulation, tariffs, inadequate financial supervision, absence of the rule of law and other impediments to investment. As recent experience in Asia, and earlier experience in Mexico, Argentina, Russia, Ukraine and elsewhere demonstrates, loans and liquid resources often allow countries to delay reform. More systematic research, Dollar (1998) shows that foreign aid and liquidity do not produce development, and may retard development unless a country decides to implement structural reforms.

Critics also made much of the elimination of (ex post) conditionality. There are three main reasons behind this decision. First, as the Report notes, there is no evidence that conditionality makes a difference on average. There are well-known problems in testing for the effects of conditionality, but the tests that have been reported, both within the IMF and outside, do not show economically important effects. Second, the majority believes that local decisions should be encouraged in the interests of democratic accountability. Crises have become the occasion for IFI's to demand reforms that domestic majorities do not want and that governments will not enforce. Third, negotiating a long list of conditions delays action at times of crisis, deepening and spreading the crisis. Delay was very damaging to Mexico, Korea, and others.

The Treasury claims that the majority proposal "would preclude the IMF from being able to respond to financial emergencies in a potentially large number of its member countries." U.S. Treasury (2000, p. 7). This statement brings out clearly the principal difference in orientation between the Commission majority and many of its critics. The Treasury claims that countries would not respond to the incentives despite the fact that private lenders and investors annually provide 50 to 100 times the amount of financial resources advanced by all the IFI's. They would not reform to meet the preconditions, so they would not qualify for assistance.

Let me grant this proposition for the moment. If it were true that most countries would not reform to gain access to financial markets and to enhance stability, what reason is there to believe that these countries will reform because the IFI's exhort them to do so and offer a tiny fraction of the resources they could acquire by reforming?

The majority report proposes to use market discipline in place of conditionality. Publication of timely, accurate information on economic, financial and political developments permits lenders and

\footnotetext{
${ }^{6}$ It is easy to see how fiscal profligacy can waste resources and slow growth. More difficult is how fiscal profligacy can continue in developing countries if it is not financed by domestic banks or foreign lenders.
} 
investors to make informed decisions. The IMF has a major role in improving the quality and increasing the quantity and timeliness of country data. Publication of reports of IMF missions and the IMF's recommendations is a welcome development. Improved information reduces uncertainty and improves lenders' decisions. Release of information encourages reform and permits investors to make continuous marginal adjustments instead of rushing to exit when anticipations change quickly. Further, improving information and opening the economy to foreign banks reduces reliance on renewable, short-term loans. Thus, it reduces one of the major problems of development finance, excessive reliance on short-term loans.

Many of the Commission's critics want to continue conditional lending after crises occur. Few, if any, defend the large number of conditions, often more than 20 but reaching 140 separate conditions on Indonesia's loan in the late 1990s. None show that the conditions are not in conflict, are enforced, are helpful to the country, or are related to macroeconomic stability. It is gratifying to report that the IMF has decided to shorten the list of conditions that countries must meet to receive assistance. Like the majority, it proposes to shift its emphasis toward crisis prevention and reform of financial systems, and it will urge countries to avoid adjustable, pegged exchange rates. The IMF has greatly increased publicly available information about its decisions and actions, and it has encouraged member governments to do the same. The Treasury endorses these changes.

Unfortunately, the IMF has not accepted the full logic of the Commission report. Its members debate whether and how lenders can be "bailed-in" to force them to share the cost of a financial crisis. In practice, investors are "bailed in" unless the IMF helps the country support a pegged exchange rate by lending enough to allow creditors to leave. A floating exchange rate raises the cost to the lenders who decide to bail out.

Under the majority proposal, countries that fail to satisfy pre-conditions for stability would not receive assistance until they implement reforms. Higher interest rates compensate lenders for taking the risk of lending to countries with weak financial systems or profligate policies. The lenders should bear the losses in a crisis so that they, and others, will know that the risk premiums they collect are payments that compensate for expected losses that they will bear. They would then price loans and assets correctly. A related issue, known as "moral hazard," arises in international lending when governments or IFI's permit lenders to believe that they will be bailed out in a crisis. Most critics of the Report's discussion of moral hazard accept that moral hazard was encouraged by official policies in the 1994 Mexican crisis and contributed to the Russian debacle in 1998. Lenders received large payments for bearing risk, but they believed that the principal governments or the IFI's would prevent a Russian default.

Critics deny that moral hazard was present in Asia. They point to the lack of evidence in interest spreads and other market measures. Such data are not compelling, in part because they do not address 
whether the loans were correctly priced. These data are consistent with moral hazard. If lenders priced the risk correctly, spreads would not change.

There is an additional problem. In Mexico, Thailand, and Korea the government responded to the first large withdrawals by guaranteeing the dollar value of loans to foreign, private sector lenders. The guarantee took different forms. What matters is that the local government could not honor the guarantee in the event of a run unless foreign governments or IFI's provided the dollars. The guarantee postpones or prevents capital from leaving only if the lenders believe that the guarantee will be honored by the IMF (or others). In most cases, this assumption has been at least partly correct. The finance minister knows that he must depend on assistance. The lenders act on the presumption that they will collect the risk premium but will not bear the full risk. This is moral hazard.

A related criticism is that the majority's approach requires the IMF to impose a "standstill," to prevent lenders from withdrawing from countries in crisis. This is false. The majority relies instead on a flexible exchange rate. The government would not borrow and pay out foreign exchange; the central bank would not support the currency. The exchange rate would fall until those who chose to exit were matched by private investors willing to lend or acquire assets at what they think are bargain prices. Settlement of the outstanding foreign currency claims of bondholders and lenders would be left to negotiation by the parties, as the Report notes. Recent experience in Ecuador (and elsewhere) suggests that agreements can be reached within a reasonably short time.

The majority does not believe that its proposal is painless. There are costs for the lenders and for the country. The answer does not lie in short-term solutions that force lenders to remain by imposing a "standstill". That policy would lead to an excessive reduction in the flow of loans and development finance. There are better policies. ${ }^{7}$

Part of the solution lies in letting financial institutions compete in the local market. They would hold both assets and liabilities denominated in local currency, so they would be less exposed to exchange rate risk. Opening the financial system would encourage entrants with a long-term commitment, thereby reducing the current excessive reliance on short-term capital. And, foreign banks would bring expertise in risk management and act as relatively safe havens if a crisis arises.

The IMF's Poverty Reduction and Growth Facility (PRGF) makes long-term loans at concessional interest rates to relatively poor countries. Development lending is the responsibility of the development banks. If these banks did a better job, there would be no need for the PRGF. The majority

\footnotetext{
${ }^{7}$ The Treasury and other critics are right when they claim that limiting IMF loans to 90 days with one renewal, as the majority recommended, is too short. The Commission made this recommendation after testimony and discussion with lawyers who raised issues about subordination limiting IMF of other debt to IMF loans of longer maturity. I accept this criticism. A year would have been a better choice.
} 
solution is to strengthen the development banks instead of adding another development bank within the IMF.

IMF staff are reluctant to criticize the development banks publicly, so they offer another rationale for the PRGF. The countries receiving long-term assistance do not require other types of IMF lending; PRGF makes membership attractive. The majority believes that duplication, without effective competition is costly. The IMF does not have the experience or expertise and should not develop it. The proper solution is to make the development banks more effective.

\section{The Development Banks}

The development banks' main problems are that their programs lack focus, are often loosely related, or unrelated, to their stated goals and, all too frequently fail to accomplish their objectives. After decades of programs and billions of dollars, many of the poorest nations have lower living standards than in the past. All of the fault does not lie with the development banks, but they have not found ways around the obstacles that some governments create. And they continue to lend despite the obstacles and the resulting failures.

Countries have made substantial progress where they have strengthened institutions and the role of markets and little if any progress in many of the poorest countries, where they have not reformed. Dollar (1998). Most of the very poor countries have large debts that cannot be serviced or repaid. The Commission voted unanimously to forgive the debts entirely, after countries institute reforms. The IFI's have more than enough accumulated reserves and provisions for loss to write off all debts of the poorest countries. I believe that reform of the IFI's and the recipient nations should be a pre-condition for donor country funding of debt forgiveness.

The majority favored major changes to focus efforts on three broad areas and improve incentives in the countries and the development banks. First, the development banks should work to improve the quality of life, even in countries where corruption or institutional arrangements prevent or hinder economic development. The majority proposed grants, instead of loans, to pay up to $90 \%$ of project costs approved by the development banks. To increase achievement and reduce waste, grants would be given after competitive bidding and would require independent monitoring and auditing of results. Payments would be made, after performance is certified, directly to providers or suppliers instead of governments. The suppliers would have an incentive to assure that inoculations are made, potable water is supplied, sanitation is improved, literacy rates increase, and that these and other programs produce measurable results. Secretary Summers now endorses the use of grants in place of loans. 
Second, long-term subsidized loans to develop effective institutions would assist countries that willingly adopt and sustain the necessary reforms. Here, too, independent auditors must certify that progress continues.

Third, many problems that prevent development or reduce the quality of life are common to many different countries. The development banks have maintained a country-specific focus. They have not tried to find solutions to common problems such as malaria, measles, tropical agriculture, and many others. Research is costly, and individual market demand is too small to induce companies to do the research. By joining countries together and subsidizing research efforts, the development banks can close the gap between social and private rates of return.

The majority recommended also that scarce official financial resources be concentrated on poor countries without access to alternative funds and that countries graduate automatically and regularly from the programs. Graduation would release more money to help the poorest countries. The development banks should continue to offer technical assistance to countries that graduate, but these countries should borrow in the market and be subject to market discipline.

The World Bank and others responded to the majority proposals by claiming that ending loans to middle income countries would harm the poorest countries by reducing the Bank's income. This claim has no merit. The Bank lends at a rate very little above its own cost of funds; it adds a fractional fee to cover administrative expense. The only "profit" on the loan comes from the allocation of a portion of the Bank's costless equity capital. The same capital would be available to support grants. There would be no diminution of resources.

At times, some Bank officials claim that the Bank has unlimited borrowing capacity in the capital market. Hence, its loans could be increased indefinitely, and there is no reason to shift loans from middle income countries toward the poorest countries. This is either a misstatement or an error. The Bank's borrowing limit is set by its industrialized member callable capital--the amount that countries have pledged to the Bank. Lender's risk increases once the Bank's loans approach the amount of its industrialized country callable capital, so lenders would demand higher interest rates to cover the increased risk. Given its history of rolling over uncollectable debts, the risk premium would rise rapidly. The Bank's borrowing capacity is unlimited only if the industrialized countries are willing to supply unlimited contributions to the bank's borrowing capacity.

In his testimony before the Commission and in subsequent comments, the Bank's president claimed that replacing loans to poor countries with grants was a good idea in principle, but impractical. ${ }^{8}$

\footnotetext{
${ }^{8}$ U.S. Treasury (2000, p. 8) opposes the proposed automatic graduation rule $(\$ 4000$ per capita income or investment grade rating). It does not make its own graduation proposal, but argues that most of the world's poor live in countries like China that would have graduated under the Commission's proposal. One of the Commission's
} 
He claimed it would require a large increase in support by donor countries. This claim is the very opposite of "unlimited borrowing capacity," but it too, is incorrect.

The Bank earns all of its net income by investing funds it has not disbursed and its own costless, paid-in capital in the securities market. These earnings would remain. As outstanding concessional loans are repaid, the volume of earning assets would increase. Would the available resources be large enough to support a large grants program?

After the Report was published, a senior staff member analyzed the amount of development programs that the Bank could support with current resources, if it replaced loans with grants, as the majority proposed. The calculation showed that the value of programs that could be financed with grants greatly exceeded the amount provided by traditional concessional loans now made. Lerrick (2000). Hence the amount of assistance would increase. Effectiveness would improve. Theft and misappropriation would be reduced. And there would be no debt burden for the poorest countries.

Several months after the Report appeared, a private foundation adopted the Commission's grants proposal, with monitoring, as part of a new health program for African nations. Treasury Secretary Summers has also shifted the Treasury's position. His statements at the time of the Prague meeting of the IMF and the World Bank favor increased use of grants.

The Bank's president offered another defense of Bank loans to middle income countries that can borrow in the capital markets. He claims that the Bank finances socially useful projects that do not earn monetary returns. Further, he claims that the capital markets would not finance these projects.

This argument overlooks an important difference. The Bank receives a government guarantee of principal and interest. If private lenders received the same guarantee, they would not care what the loan financed.

In fact, the Bank does not know what its loans to middle income countries finance on the margin. Money is fungible. No outsider can know reliably which project or projects were financed by development aid. It is in the interest of the country and the Bank's officers to claim high marginal social returns. In most cases, projects with high returns could be financed without assistance from the IFI's, especially if the country guarantees repayment.

This problem arises in all but the poorest countries where there is true additionality. That's another reason why the development banks should focus on poor countries without access to financial markets. 


\section{Conclusion}

The international economy has experienced several prolonged, deep financial crises in the past twenty years. At the same time, economic development has bypassed the poorest countries. Many of them are in Africa, but extreme poverty can be found also in Latin America, Asia, and southern and eastern Europe.

Reform of the international financial institutions is needed to increase economic stability, improve the flow of information, encourage economic development, support institutional reform, reduce poverty, and support provision of regional and global public goods. The Report of the International Financial Institution Advisory Commission offers an integrated approach to many of these problems.

This paper develops the Commission majority's main recommendations and responds to criticisms by the U.S. Treasury and others. It is useful to conclude by putting these criticisms into context in two ways. First, although the Treasury is critical of many of the majority's recommendations, they write: "[W]e share the Commission's desire to find new ways to encourage countries to reduce their vulnerability before crisis strikes. In this context, we agree with the report that it is critical for countries to strengthen the financial sector, improve the quality of disclosure, and reinforce the resilience of the exchange rate regime." U.S. Treasury, (2000, p. 8).

Second, it is encouraging that, with the passage of time, and more consideration, the Treasury has endorsed, and the IMF has adopted or considered, some of the majority's recommendations. The changes already adopted include reduction in the number of different lending arrangements, incentives for countries to repay more quickly, penalties in the form of higher interest rates for countries that remain in debt, and agreement that the IMF will emphasize short-term lending. Perhaps of greatest importance, the IMF has changed the Contingent Credit Line (CCL) to make it more attractive. The Contingent Credit Line is the arrangement countries use to pre-qualify, as the Commission urged.

This is a promising response to the Commission and other critics. More remains to be done. The most difficult, but most important, change is to recognize that the CCL can only work if lenders to nonCCL countries are required to take the losses implied by the risk premiums they receive.

Finally, I would welcome the opportunity to cite important reforms at the World Bank and the development banks. Regrettably, the development banks have moved more slowly, or not at all. One must hope that they will shift from a policy based on "bribe and exhort" to incentive-based policies before there is another crisis. 


\section{Bibliography}

Dollar, David, (1998). Assessing Aid. Oxford University Press for the World Bank.

The Economist, (2000). Emerging Market Indicators", (November 4), p. 118.

Lerrick, Adam, (2000. "Development Grant Financing: More Aid per Dollar." Hearing before the Joint

Economic Committee. Washington: Government Printing Office (April 12).

Reform of the International Monetary Fund, (2000). Hearing before the Subcommittee on International

Trade and Finance, 106th Congress, 2nd session. Washington: Government Printing Office, April 27.

U.S. Treasury, (2000. Response to the Report of the International Financial Institution Advisory Commission. Washington: Department of the Treasury, June 9.

World Bank, (1992). "Effective Implementation: Key to Development Impact." Washington: The World Bank. Internal document, (The Wapenhans Report). 